\title{
A Comparison between the Results of Hormuz Strait Wave Simulations Using WAVEWATCH-III and Satellite Altimetry Observations
}

\author{
Sharifi FS* and Ezam M \\ Islamic Azad University, Iran
}

Submission: February 19, 2017; Published: March 24, 2017

*Corresponding author: Sharifi FS, Graduate school of marine science and technology, Science and Research branch, Islamic Azad University, Iran, Email: ekokinou@staff.teicrete.gr

\begin{abstract}
In the present study, the capabilities of WAVEWATCH-III model for predicting wind-induced wave characteristics in the Hormoz Strait area are investigated. The input wind data were extracted from GFS (Global Forecast System) and introduced to the model with $5^{\circ} \mathrm{C}$ spatial resolution and 6 hours time steps. The bathymetry data, introduced to the model with 2 arc-minute spatial resolutions, also were derived from the ETOP01. After the model was setup using aforementioned wind and bathymetry data, the effect of surface layer instability on wave growth was studied through considering the monthly averaged air-sea temperature difference. Results show that, during cold months when the surface layer is unstable, taking the air-sea temperature difference into account, the accuracy of model is enhanced in predicting significant wave height. A comparison between satellite altimetry observations and numerical simulation results suggest that, in January, the surface layer instability effects in the numerical simulation leads to higher correlation between significant wave height predicted by the numerical model and that obtained from satellite altimetry observations. It should be noted that the air-sea temperature difference, during the surface layer stability period, leads to no considerable changes in numerical simulation results.
\end{abstract}

\section{Introduction}

\section{Coastal countries}

Countries bordering large water body need to deal with considerable challenges with respect to development and management of coastal areas. Therefore, it is necessary to organize comprehensive study programme to investigate the wave climate systematically [1-3]. In Iran, having more than $5000 \mathrm{~km}$ coastline along the Caspian Sea, Persian Gulf and Oman Sea, a profound deep understanding of wave climate is very worthwhile in any coastal and offshore development plans. In this regard, field investigations, physical models and numerical simulations are the most common methods of predicting natural phenomena in ocean waters.

Wind-induced waves are among the most important waves in marine environment. Strong wind waves which are generated during storms may be damaging and cause flooding in coastal areas. Hence, a reasonable prediction of wind wave characteristics is an indispensible part of an economical and reliable design of coastal and offshore facilities [4-6].
In the present study, the WAVEWATCH-III, a third generation spectral wave model Tolman et al. 1997, was utilized to study the effect of surface layer instability on growth of wind induced waves in the Hormoz Strait. The WAVEWATCH-III, based on rectangular structured grids, was developed by NOAA, in the spirit of the WAM model. It is the further development of WAVEWATCH and WAVEWATCH-II, which were developed by Delft University of Technology and NASA Goddard Space Flight Center respectively. WAVEWATCH-III differs from its predecessors in many aspects including; governing equations, numerical schemes, model structure and physical parameterization. For more details see Tolman et al. 1997. In this study, the effect of surface layer instability is studied via the air-sea temperature difference which is included explicitly in Tolman Chalikov source term package [7-10].

\section{Conclusion}

In the present study, the effect of air-sea temperature difference on numerical simulation of wind-wave in the Hormoz 
strait region was examined. All numerical simulations were carried out using the WAVEWATCH-III, using the GFS wind data and ETOPO1 bathymetry data. The model is forced by the Global Forecast System (GFS) data. Bathymetry data is also taken from the ETOP01. Results of the numerical simulations suggest that in the periods of time when $\Delta \mathrm{T}_{a s}<\mathrm{O}$ and consequently the surface layer is unstable, the effect of air sea temperature difference leads to a better agreement between the numerical simulation results and satellite altimetry observations [11-14].

\section{References}

1. Battjes JA, Janssen JPFM (1978) Energy loss and set-up due to breaking o random waves. In Proceeding of coastal engineering, $16^{\text {th }}$ conference, USA.

2. Booij N, Ris RC, Holthuijsen LH (1999) A third generation wave model for coastal regions. 1. Model description and validation. Journal of Geophysical Research 104(4): 7649-7666.

3. Cavaleri L, Sclavo M (2006) The calibration of wind and wave model data in the Mediterranean Sea. Coastal Engineering 53(7): 613-627.

4. Caires S, Sterl A (2005) A new nonparametric method to correct model data: Application to significant wave height from the ERA-40 re-analysis. Journal of Atmospheric and Oceanic Technology 22(4): 443-459.

5. Caires S, Sterl A (2005) 100-Year Return value estimates for ocean wind speed and significant wave height from the ERA-40 data. Journal of Climate 18(7): 1032-1048.
6. Hafeznia M (2004) Strategic Roles of Hormuz Strait. Mehr ISSUANCES, Iran.

7. Hasselmann K (1973) Measurements of wind-wave growth and swell decay during the Joint North Sea Wave Project (JONSWAP). Ergänzung zur Deut Hydrogr Z 8(12):1-95.

8. Komen GJ, Hasselmann S, Hasselmann K (1984) On the existence of a fully developed wind-sea spectrum. Physical Oceanography 14(18): 1271-1285.

9. Moeini MH, Etemad Shahidi A (2007) Application of two numerical models for wave hindcasting in Lake Erie. Applied Ocean Research 29(3): 137-145.

10. Phillips OM (1957) On the generation of waves by turbulent wind. Fluid Mech pp 2(5): 417-445.

11. Signell RP, Carniel S, Cavaleri L, Chiggiato J, Doyle JD, et al. (2005) Assessment of wind quality for oceanographic modelling in semienclosed basins. Journal of Marine Systems 53(1-4): 217-233.

12. The WAMDI Group (1988) The WAM Model - A third-generation ocean wave prediction model. Journal of Physical Oceanography 18(12): 1775-1810.

13. Tolman HL (2002) User manual and system documentation of WAVEWATCH- III Version 2.22. Environmental Modeling Center, Ocean Modeling Branch Contribution, Washington, USA

14. Sharifi FS, Ezam M, Karami Khaniki A (2012) Evaluating the Results of Hormuz Strait Wave Simulations Using WAVEWATCH-III and MIKE21SW. Int J Mar Sci Eng 2(2): 163-170.

\section{Your next submission with Juniper Publishers will reach you the below assets}

- Quality Editorial service

- Swift Peer Review

- Reprints availability

- E-prints Service

- Manuscript Podcast for convenient understanding

- Global attainment for your research

- Manuscript accessibility in different formats

( Pdf, E-pub, Full Text, Audio)

- Unceasing customer service

Track the below URL for one-step submission https://juniperpublishers.com/online-submission.php 